\title{
Afiks Infleksi dan Derivasi dalam Bahasa Gorontalo
}

\author{
Ainun Abdullah \\ Dakia N. Djou \\ Sitti Rachmi Masie \\ Fakultas Sastra dan Budaya, Universitas Negeri Gorontalo \\ Pos-el: ainunhabibi2019@gmail.com \\ dakiadjou.ung@gmail.com \\ sirachma80@gmail.com
}

\section{DOI: 10.32884/ideas.v6i4.305}

\begin{abstract}
Abstrak
Penelitian ini bertujuan mendeskripsikan afiks infleksi dan mafiks derivasi dalam bahasa Gorontalo. Metode penelitian yang digunakan dalam penelitian ini adalah metode deskriptif kualitatif. Teknik pengumpulan data menggunakan teknik simak dan rekam. Data yang diperoleh dalam penelitian ini adalah kata-kata berimbuhan dalam bahasa Gorontalo yang mengandung afiks infleksi dan mengandung afiks derivasi. Hasil penelitian ini menunjukkan bahwa afiks infleksi dalam bahasa Gorontalo terjadi dalam prefiks mo- yang digabungkan dengan verba, prefiks popo- digabungkan dengan verba, prefiks lo- digabungkan dengan verba, prefiks moti- digabungkan dengan verba, infiks -il- digabungkan dengan verba, konfiks po- dan -lo digabungkan dengan verba, sufiks -lo digabungkan dengan verba. Sedangkan hasil penelitian afiks derivasi dalam bahasa Gorontalo menunjukkan bahwa afiks prefiks mo- digabungkan dengan nomina menghasilkan verba, prefiks mohi- digabungkan dengan nomina menghasilkan verba, prefiks ngo- digabungkan dengan nomina menghasilkan numeralia dan sufiks -lo digabungkan dengan nomina menghasilkan verba.
\end{abstract}

Kata kunci: afiks, infleksi, derivasi, bahasa Gorontalo

\begin{abstract}
This present study was purposed to describe the inflectional and derivational affixes in Gorontalo language. This study is applying qualitative and descriptive methods. The data were collected using observation and recording techniques. The obtained data in this study were the words that have inflectional and derivational affixes in Gorontalo language. The results showed that the inflectional affixes occur in the prefix mo-,prefix popo-, prefix lo-, prefix moti-,infix-il-,confix po-and-lo, and suffix-lo that combined with verbs produce verbclass. In comparison, the results of derivational affixes occur in the prefix mo-, prefix mohi,suffix-lo, confix po-that combined with nouns produce verbs; meanwhile, prefix ngocombined with nouns produces numerals.
\end{abstract}

Keywords: affix, inflection, derivation, Gorontalo language.

\section{Pendahuluan}

Bahasa merupakan alat komunikasi utama manusia dalam menjalankan kehidupan sehari-hari. Tujuannya adalah untuk menyampaikan ide serta gagasan terhadap lawan

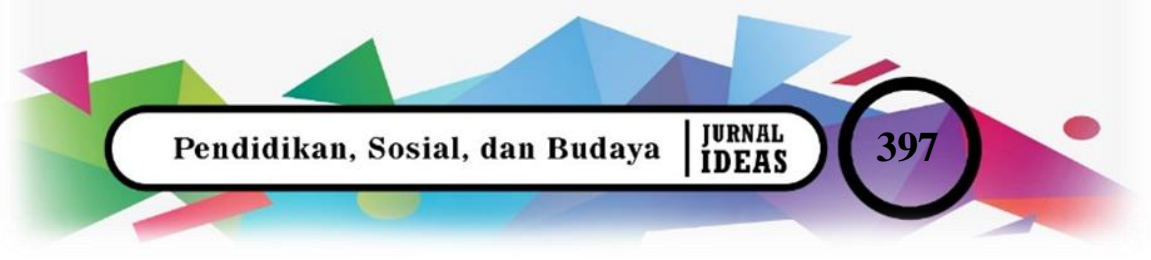


tuturnya agar lawan tutur paham atau mengerti terhadap yang dimaksudkan atau yang dibicarakan.

Setiap bahasa yang dituturkan tidak lepas dari fonem atau bunyi-bunyi bahasa yang membentuk sebuah morfem dan kata. Ketika seseorang bertutur kata, patutlah ia memperhatikan setiap bunyi bahasa dan morfem yang diujarkan. Hal tersebut karena jika sebuah fonem yang dikeluarkan melalui alat ucap tidak sesuai dengan bentuk morfem dan kata yang dimaksudkan, akan menghasilkan makna yang ambiguitas atau bahkan berujung pada penafsiran makna berbeda dari makna kata yang sesungguhnya. Hal ini sejalan dengan pendapat (Pateda, 2002: hlm. 5) bahwa satuan terkecil dalam bahasa adalah bunyi bahasa yang dalam linguistik disebut fonem. Jika bunyi bahasa itu dirangkai-rangkai, terbentuklah morfem dan kata.Disiplin ilmu yang mempelajari morfem dan kata disebut morfologi.

Secara etimologi, kata morfologi berasal dari kata morf yang berarti'bentuk' dan kata logi yang berarti 'ilmu. Jadi, secara harfiah, kata morfologi berarti 'ilmu mengenai bentuk'. Kajian linguistik menyebutkan bahwa morfologi berarti 'ilmu mengenai bentukbentuk dan pembentukan kata' (Chaer, 2008: hlm. 3). Pendapat Chaer sejalan dengan pendapat (Pateda, 2002: hlm. 5) bahwa morfologi merupakan subdisiplin linguistik yang mengkaji bentuk kata, perubahan bentuk, dan makna yang timbul akibat perubahan bentuk itu.

Menurut Aronoff dan Fudeman (dalam Sunardi, 2012: hlm. 1), dalam ilmu linguistik, istilah morfologi (morphology) dipakai untuk menyebut sistem mental yang terlibat dalam pembentukan kata atau cabang ilmu linguistik yang berkenaan dengan kata, struktur internal kata, dan bagaimana kata tersebut dibentuk. Crystal (dalam Anggriani, 2020: hlm. 2) menjelaskan bahwa morfologi adalah cabang tata bahasa yang menelaah struktur atau bentuk kata, utamanya melalui penggunaan morfem. Alwasilah (dalam Kasman, 2011: hlm. 3) mengemukakan bahwa morfologi adalah suatu cabang dari ilmu bahasa (linguistik) yang mempelajari dan menganalisis struktur, bentuk, klasifikasi kata-kata (Ramaniyar, 2016: hlm. 2) menjelaskan bahwa objek morfologi adalah hal-hal yang berhubungan dengan bentuk kata atau struktur kata dalam bahasa. Morfologi termasuk salah satu studi kebahasaan (linguistik) yang mengkaji kata atau leksikon suatu bahasa (Pumanto, 2016: hlm. 136). Morfologi adalah bidang bahasa yang mengkaji tentang bentuk kata hingga perubahan makna katanya. Hal ini senada dengan pendapat Bauer (dalam Purwanto, 2006: hlm. 137) bahwa 
morfologi adalah bidang linguistik yang dipahami sebagai studi tentang perubahan-perubahan secara sistematis tentang bentuk kata yang dihubungkan dengan maknanya. Selain itu, ada beberapa pendapat lain yang seirama dengan dua pendapat ahli di atas (Putrayasa, 2008: hlm. 3) menjelaskan bahwa morfologi adalah bagian dari ilmu bahasa yang membicarakan atau mempelajari seluk-beluk struktur kata serta pengaruh perubahan-perubahan struktur kata terhadap kelas kata dan arti kata. Selain morfologi mempelajari pembentukan kata dan perubahannya, juga mengkaji kemungkinan adanya golongan arti kata yang muncul, sebagai akibat perubahan bentuk kata (Luwiti, 2009: hlm. 1).

Morfologi adalah bagian dari ilmu bahasa yang membicarakan atau mempelajari selukbeluk struktur kata serta pengaruh perubahan-perubahan struktur katater hadap kelaskatadanarti kata (Putrayasa, 2008: hlm. 3).Terdapat ranah infleksi dan derivasi dalam bidang morfologi. Kedua ranah ini terjadi pada tahap morfemis. Parera (2007: hlm. 18) menyatakan bahwa proses morfemis merupakan pembentukan kata bermorfem jamak baik derivatif maupun inflektif. Djajasudarma (dalam Putrayasa, 2008: hlm. 2) menjelaskan bahwa derivasional bersifat mengubah kelas kata,sedangkan infleksional bersifat tidak mengubah kelas kata.

Asal-usul terbentuknya kata dalam morfologi seperti beristri itulahyang dibicarakan secara lebih detail. Matthews (dalam Ridwan, 2015: hlm. 2) menggolongkan morfologi menjadi dua bidang, yaitu morfologi infleksional dan morfologi leksikal. Morfologi infleksi merupakan prosses morfemisyang menghasilkan bentuk kata yang berbeda dari leksem dasar. Proses infleksi berkaitan dengan mengubah sebuah bentuk kata untuk menetapkan hubungannya dengan kata lain dalam kalimat atau menandai hubungan sintaksis. Proses infleksi ini tidak menghasilkan kelas kata baru. Sedangkan proses derivasi mengubah suatu kata menjadi kata baru. Kata baru itu pada umun yang menduduki kelas yang berbeda atau lain jenisnya dengan kata yang belum mengalami proses derivasi.

Terdapat dua istilah dalam pembentukan kata yaitu infleksi dan derivasi. Kedua istilah ini sama-sama digunakan dalam ranah morfologi. Crowley (dalam Sukri, 2015: hlm. 126) menambahkan bahwa sebuah bahasa mempunyai seperangkat kaidah yang menentukan cara morfem dapat digabungkan bersama untuk membentuk unit atau kesatuan yang lebih besar yang disebut kata.

Terdapat afiksasi dalam proses pembentukan kata yang menunjang dan menentukan apakah makna yang dihasilkan berubah (derivasi) akibat afiks yang disematkan dibentuk atau 
makna yang dihasilkan tidak berubah (infleksi) dari makna bentuk dasamya. Hal ini sejalan dengan pendapat (Romli, 2015: hlm. 3) bahwa afiksasi juga merupakan unsur yang ditempelkan dalam pembentukan kata. Afiksasi dalam linguistik bukan merupakan pokok kata melainkan pembentukan pokok kata yang baru.

Ranah infleksi dan derivasi adalah dua hal yang sangat berbeda. Hal ini karena infleksi lebih merujuk pada penambahan afiksasi yang tidak mengubah makna dan kelas katanya, baik dari segi makna dan kelas kata pada kata dasar ataupun dari segi makna dan kelas kata setelah dilakukan proses infleksi. Sedangkan, derivasi lebih merujuk pada perubahan makna dan kelas katanya sebagai akibat dari penambahan afiksasi tersebut. Hal ini sejalan dengan pendapat Putrayasa (2008: hlm. 2) yang mengatakan bahwa penggabungan kata dasar dengan imbuhan dapat menimbulkan bentuk derivasional dan infleksional. Lebih lanjut Chaer (2008: hlm. 37) menjelaskan bahwa pembentukan kata inflektif identitas leksikal kata yang dihasilkan sama dengan identitas leksikal bentuk dasarnya. Sebaliknya dalam proses pembentukan derivatif identitas bentuk yang dihasilkan tidak sama dengan identitas leksikal bentuk dasamya. Misalnya pembentukan kata 'membeli' dari dasar kata 'beli' adalah sebuah inflektif, tetapi pembentukan kata pembeli dari dasar kata 'beli' adalah sebuah kasus derivatif. Dasar kata 'beli' dan kata 'membeli' sama-sama berkategori verba, sedangkan dasar kata 'beli' dan kata 'pembeli' tidak sama kategorinya, 'beli' adalah verba dan 'pembeli' adalah nomina. Tentunya dibalik perbedaan ini pasti ada persamaan. Ermanto (2008: hlm. 2) menjelaskan bahwa infleksi dan derivasi sama-sama memproses leksem untuk menurunkan hasil yang berbeda. Jadi, derivasi memproses leksem untuk menghasilkan leksem, sedangkan infleksi memproses leksem untuk menurunkan kata gramatikal.

Derivasi mengharuskan makna dan kelas kata yang dihasilkan oleh kata berimbuhan harus berubah dari kata dasamya. Misalnya, kata jalan mendapat imbuhan ber-menjadi berjalan. Proses ini menciptakan leksem dengan makna baru dengan kelas kata yang berbeda (Pohan, 2019: hlm. 111). Contoh infleksi dalam kalimat adalah Ayu sedang bermain sepeda milik adiknya. Kalimat ini mengandung infleksi karena kata bermain yang berasal dari gabungan ber dan main tidak mengubah makna dan kelas kata pada kata dasar (Putrayasa, 2008: hlm. 113). Contoh derivasi dalam kalimat adalah Riska sedang menyapu ruang guru. Kalimat ini mengandung pembentukan derivasi, karena pada kata menyapu mengalami perbahan makna dan kelas kata, yaitu $m e N$ - ditambahkan kata benda'sapu' akan menghasilkan kata dan makna baru yaitu menyapu yang berkategori verba (Putrayasa, 200: hlm.103). 
Pembentukan derivasi dalam bahasa Gorontalo, juga mengharuskan berubahnya makna dan kelas kata pada kata dasar ataupun pada kata yang mendapat imbuhan. Misalnya pada kata topi dan ngotopi dalam kalimat ngolo haraga lolambi ngotopi? Artinya berapa harga pisang satu sisir? Kata ngotopi berasal dari kata topi yang mendapat imbuhan ngo- di depan kata topidengan makna dan kelas kata yang telah berubah menjadi jumlah pisang satu sisir dari makna sisir pada kata topi dan berkelas kata nomina karena menunjukkan sebuah benda, sedangkan katangotopi yang berarti satu sisir berkelas kata numeralia karena menunjukkan sebuah bilangan atau jumlah suatu barang. Sehingga, imbuhan ngo- yang disematkan pada kata topi menjadi ngotopi merupakan kata yang mengalami proses pembentukan derivasi akibat afiks yang disematkan membawa perubahan makna dan kelas kata.

Morfologi infleksional adalah pembentukan kata dari asal yang sama. Artinya, infleksi tidak mengubah kategori kelas katanya dan juga tidak mengubah makna katanya. Hal ini didukung oleh pendapat ahli, Samsuri (dalam Putrayasa, 2008: hlm. 113) bahwa infleksional adalah kontruksi yang menduduki distribusi yang sama dengan dasarnya. Clark (dalamPutrayasa, 2008: hlm. 113) menambahkan bahwa infleksional adalah proses morfologis karena afiksasi yang menyebabkan terbentuknya berbagai bentukan dengan ketentuan bahwa bentukan tersebut tetap dalam kelas kata yang sama. Jadi, tidak ada perubahan kelaskata. Selain itu, afiks infleksional tergolong produktif, sedangkan afiks derivasional belum tentu tergolong produktif (Subroto, 2013: hlm. 11).

Afiks infleksional adalah afiks yang mampu menghasilkan bentuk-bentuk kata yang baru dari leksem dasamya, sedangkan afiks derivasional adalah afiks yang menghasilkan leksem baru dari leksem dasar (Pumanto, 2006: hlm. 137). Perbedaan yang dikemukakan Boiij adalah dari segi fungsinya, yakni derivasi menghasilkan leksem baru dan infleksi menghasilkan bentuk-bentuk yangberbeda dari leksem yang sama (Pohan, 2019: hlm. 109).

Morfologi derivasional atau derivasi merupakan pembentukan kata yang membentuk kata baru, kata yang identitas leksikalnya tidak sama dengan bentuk dasamya (Anggraini, dan Bayu, 2019: hlm. 23). Derivasi adalah proses imbuhan terhadap suatu suku kata yang berakibat mengubahkelas kata ataupun makna kata tersebut (Pohan, 2019: hlm. 110).

Identitas bentuk yang dihasilkan oleh pembentukan derivatif tidaksama dengan identitas leksikal. Bentuk dasarnya, misalnya pembentukan kata pembeli dari kata dasar beli adalah sebuah kasus derivatif, dasar beli dan kata pembeli tidak sama kategorinya; beli adalah verba 


\begin{tabular}{c|l} 
E-ISSH: 2656-940K & $\begin{array}{l}\text { Volume: } 6 \\
\text { Nomor: } 4 \\
\text { P-ISSH: 2442-367K } \\
\text { Bulan : November } \\
\text { URL: jurnal.ideaspublishing.co.id }\end{array}$ Tahun:2020
\end{tabular}

dan pembeli adalah nomina (Chaer, 2015: hlm. 37-38). Boey (dalam Bagiya, 2017: hlm. 34) menyatakan bahwa afiks-afiks derivasional merupakan morfem terikat yang digabungkan dengan base untuk mengubah kelas katanya (partofspeech). Misalnya bentuk kata teach, build, dan sweep merupakan verba. Kemudian mendapat afiks derivasional berupa -er, akhimya menjadi bentuk nomina teacher, builder, dan sweeper. Dalam kasus-kasus yang paling jelas, morfologi derivasional menciptakan suatu kata dari kategori sintaksis lain, sedangkan morfologi inleksional tidak mengubah satu kata menjadi kata yang lain dan tidak pernah mengubah kategori sintaksis, tetapi menghasilkan bentuk lain dari kata yang sama (Nur, 2018: hlm. 2).

Derivasi memiliki tiga kategori. Kategori pertama adalah menghasilkan leksem baru yang diderivasi. Misalnya, kata 'jalan' mendapat imbuhan derivasi 'ber' menjadi 'berjalan'. Proses ini menciptakan leksem dengan makna baru dengan kelas kata yang berbeda. Kategori kedua, derivasi adalah proses derivasi menjadi terjadi dengan tidak konsisten terhadap leksem dengan kategori kelas kata yang sama. Misalnya, imbuhan -kan dilekatkan pada kata 'hitam' menjadi 'hitamkan' yang bermakna membuat sesuatu hitam. Kategori ketiga derivasi adalah proses penggabungan akar kata dengan morfem derivasi sering dianggap tidak jelas secara makna. Misalnya, kata 'operasi'yang digabungkan dengan awalan 'ko' menjadi 'kooperasi'. Hal ini dianggap tidak merupakan proses derivasi, tetapi kenyataannya adalah proses derivasi. Oleh sebab itu, proses ini disebut proses derivasi tidak jelas secara makna (Pohan, 2019: hlm. 111). Perspektif infleksi dan derivasi ini bermanfaat untuk menjelaskan proses morfologi Bahasa Indonesia yakni (1) afiksasi, (2) reduplikasi, (3) pemajemukan (Ermanto, 2012: hlm. 15).

Secara spesifik, Bauer (dalam Pohan, 2019: hlm. 112) menyatakan bahwa derivasi adalah proses morfologis yang menghasilkan morfem baru; sedangkan infleksi adalah proses morfologis yang menghasilkan bentuk-bentuk kata yang berbeda dari sebuah leksem yang sama. Lebih lanjut Bauer menjelaskan bahwa pembentukan infleksional dapat diramalkan, sedangkan pembentukan derivasional tidak dapat diramalkan. Ermanto, (2008: hlm. 1) menjelaskan bahwa derivasi adalah proses pengubahan bentuk kata yang mengubah identitas, sedangkan infleksi adalah proses pengubahan bentuk kata yang tidak mengubah identitas.

Salah satu perbedaan derivasi dan infleksi ditunjukkan melalui perbedaan hasilnya (output), derivasi menghasilkan leksem dari suatu leksem, dan infleksi menghasilkan bentukbentuk kata dari suatu leksem. Artinya, derivasi menghasilkan sebuah kata baru dari sebuah kata lainnya. "Kata baru" (output) yang dihasilkan proses derivasi itu merupakan kata yang berbeda 
dengan kata sebelumnya (input)(Ermanto, 2016: hlm. 23). Selanjutnya, Samsuri (dalam Putrayasa, 2008: hlm. 103) menjelaskan bahwa derivasi merupakan kontruksi yang berbeda distribusi dari dasarnya. Derivasi mendaftar berbagai proses pembentukan kata-kata baru dari kata-kata yang sudah ada (atau akar, asal), ajektiva dari nomina (seasonal dari season),nomina dari verba(singer dari sing), ajektiva dari verba (acceptable dari accept), dan sebagainya, Lyons (dalam Putrayasa, 2008: hlm. 103).

\section{Metode}

Pendekatan yang digunakan dalam penelitian ini adalah pendekatan deskriptif yang mendeskrisikan infleksi dan derivasi dalam bahasa Gorontalo. Jenis penelitian ini adalah penelitian kualitatif. Ciri keenam dari jenis penelitian kualitatif adalah bersifat deskriptif, artinya data yang dikumpulkan adalah berupa kata-kata, gambar, dan bukan angka-angka, yang mungkin berasal dari naskah wawancara, catatan lapangan, foto, videotape, dokumen pribadi, catatan atau memo, dan dokumen resmi lainnya (Moleong, 2006: hlm. 11). Oleh karena itu, penelitian ini termasuk jenis penelitian deskriptif kualitatif yaitu menggambarkan atau menguraikan setiap kata yang mengalami infleksi dan derivasi dalam bahasa Gorontalo.

Teknik pengumpulan data yang digunakan dalam penelitian ini adalah teknik simak dan teknik rekam.Teknik simak adalah teknikyang digunakan untuk memperoleh data yang dilakukan dengan menyimak penggunaan bahasa, baik secara lisan maupun penggunaan bahasa secara tertulis, teknik simak pun memiliki teknik dasar yaitu penyadapan, karena hakikat penyimakan diwujudkan dengan penyadapan (Mahsun, 2012: hlm. 92). Teknik rekam ditujukan untuk merekam setiap pembicaraan antar informan. Mahsun(2012: hlm. 93) menjelaskan bahwa teknik rekam dimungkinkan terjadi jika bahasa yang diteliti adalah bahasa yang masih dituturkan oleh pemiliknya. Hal ini karena bahasa yang diteliti yaitu di Kelurahan Polohungo ini langsung dituturkan oleh pemilik dan pengguna bahasa Gorontalo, maka teknik rekam digunakan sebagai teknikpengumpulan data.

\section{Hasil dan Pembahasan}

Pada bagian ini dipaparkandan dideskripsikan data hasil penelitian yaitu afiks infleksi dan derivasi dalam bahasa Gorontalo.

\section{Hasil}

\section{Afiks Infleksi dalam Bahasa Gorontalo}

a. Prefiks mo- digabungkan dengan verba 


\section{Kalimat (1)}

Po'opiyo hemohi sapatu, alihu diya gambangi mopetu'a wo numetedu'ato botu.

Artinya:

Perbaiki cara memakai sepatu, supaya tidak gampang terkilir kalau terantuk pada batu.

Dalam data di atas (kalimat 1), terdapat kata yang mengalami infleksi, yaitu kata mopetu'a yang berarti terkilir. Kata mopetu'a ini memiliki ciri dari kata berinfleksi, yaitu memiliki imbuhan. Imbuhannya tidak mengubah makna kata, serta imbuhannya tidak mengubah kelas katanya. Sehingga, kata mopetu'a disebut sebagai kata berinfleksi.

Kata mopetu'a terdiri atas kata dasar petu'a yang bermakna kilir, dan terdiri atas imbuhan mo- yang disematkan di depan kata dasarnya. Kata petu'a dan mopetu'a memiliki makna yang tidak jauh berbeda, yaitu terkilir dan memiliki kelas kata yang sama, yaitu verba. Sehingga, kata mopetu'a 'terkilir' termasuk dalam kata berinfleksi dalam bahasa Gorontalo.

b. Prefiks Popo- digabungkan dengan Verba

\section{Kalimat (1)}

Donggo mowali uwitobutulu losampo, de popohalantuyiyolo butulu liyo alihu tuwangolo sampo boyito mokaluari mayi.

Artinya:

Botol sampo itu masih bisa dipakai, nanti dibalikkan botolnya, agar isi sampo itu akan keluar.

Data (kalimat 1) di atas menunjukkan bahwa kata yang mengalami infleksi adalah kata popohalantu yiyolo 'dibalikkan'. Kata popohalantu yiyolo 'dibalikkan' berasal dari kata dasar halantuyi 'balik' yang mendapat imbuhan popo- di depan kata dasarnya. Imbuhan popo- tersebut tidak mengubah makna kata popohalantuyiyolo dengan makna kata halantuyi, sebab kedua kata tersebut samasama mengandung makna membalikkan sebuah benda. Kelas kata yang dihasilkan juga sama,yaitu verba. Sehingga, kata halantuyi menjadi popohalantuyiyolo adalah kata berinfleksi dalam bahasa Gorontalo.

c. Prefikslo-digabungkan dengan Verba

\section{Kalimat 1}

Olangowatiyalota'odu huidutilalalolambango oato latiyalopetu'a.

Artinya:

Kemarin saya mendaki gunung, lalu kaki saya salah melangkah sehingga terkilir. 
Dalam data (kalimat 1) di atas, terdapat kata lota'odu yang mengalami infleksi. Hal ini karena kata lota'odu' mendaki' memilikiarti yang tidak jauh berbeda dengan kata dasarnya, yaitu ta'odu'daki, panjat, naik'. Kata lota'odu dan ta'odu juga berkelas kata yang sama, yaitu verba. Sehingga, kata lota'odu dan ta'odu termasuk dalam kata yang berinfleksi.

d. Prefiksmoti- digabungkan dengan Verba

\section{Kalimat 1}

Watiyao hilamoti'oyohu todutula.

Artinya:

Saya ingin berenang di sungai.

Data di atas menunjukkan bahwa terdapat satu kata yang mengalami infleksi,yaitu kata moti'oyohu 'berenang', sebab kata moti'oyohu 'berenang' merupakan kata yang mendapat imbuhan moti- di depan kata dasarnya, dan imbuhan tersebut tidak membawa perubahan makna yang jauh berbeda dengan makna kata dasarnya. Terlihat pada kata dasar oyohu yang berarti renang menjadi moti'oyohu berenang akibat imbuhan motiyang tersemat diawal kata dasamya. Kata moti'oyohu 'berenang' berkelas kata verba,dan kata oyohu'renang' juga berkelas kata verba. Sehingga, kata moti'oyohu 'berenang' dinyatakan sebagai kata berinfleksi dalam bahasa Gorontalo.

e. Infiks - il- digabungkan dengan Verba

\section{Kalimat (1)}

Batade Le Pakuni madidu hilama liyo, sababu tiyo mayi loyingo.

Artinya:

Kambing Si Pakuni sudah tidak diambil, sebab dia sudah marah.

Dalam tabel 2 diatas, terdapat kata hilama 'diambil' yang kata dasamya adalah kata hama 'ambit'. Kata hilama 'diambil' merupakan kata yang mendapat imbuhan infiks di tengah kata dasarnya, yaitu infiks -il-. Imbuhan tersebut tidak membawa perubahan yang berbeda dan kedua kata tersebut memiliki kelas kata yang sama, yaitu verba. Sehingga, kata hilama 'diambil' adalah kata berinfleksi dalam bahasa Gorontalo.

\section{f. Sufiks -lo digabungkan dengan Verba}

Kalimat (2)

Ma longgalo lowatopo boyito, sababu watopo liyo mahemoluhe wanu ode huwa lodidi.

Artinya:

Akan dibongkar atap itu sebab atapnya sering basah kena air hujan.

Data pada (kalimat 2) di atas memperlihatkan,bahwa kata longgalolo 'dibongkar' adalah kata yang mengalami infleksi, karena kata longgalolo 'dibongkar' memenuhi ciri dari 
kata berinfleksi, yaitu imbuhan yang disematkan, baik di awal kata, akhir kata, dan di tengah kata, haruslah mengandung makna serta kelas kata yang sama dengan makna dan kelas kata pada kata dasarnya. Begitu pun dengan kata longgalolo 'dibongkar' yang menghasilkan makna kata yang sama dengan kata dasarnya longgalo 'bongkar', serta kelas kata yang dihasilkan juga sama, yaitu verba. Sehingga, kata longgalolo'dibongkar' dinyatakan sebagai kata berinfleksi dalam bahasa Gorontalo.

g. Konfiks $p o^{\prime} o-$ dan $l o-$

Kalimat (1)

De mapo'olapato lo binte botiye.

Artinya:

Nanti akan diselesaikan (proses menanam) jagung ini.

Data di atas menunjukkan bahwa kata berinfleksi terjadi pada kata po'olapatolo 'diselesaikan' dengan imbuhan konfiks po'o- dan-lo yang melekat diawal dan akhir kata dasarnya.Kata lapato di maknai selesai yang merujuk pada kelas kata verba karena menyatakan kata kerja, dan kata po'olopatolo bermakna diselesaikan, yang berkelas kata verbakarena maknanya menerangkan sebuah pekerjaan yang akan diselesaikan. Sehingga, kata po'olopatolo dinyatakan sebagai kata yang mengalami infleksi dalam bahasa Gorontalo.

\section{Derivasi dalam bahasa Gorontalo}

a. Prefiks mo-digabungkan dengan Nomina menjadi Verba

Ja lipata poli modu'a.

Artinya:

Jangan lupa lagi berdoa.

Kalimat 1 di atas menunjukkan bahwa kata modu'a 'berdoa' mengalami derivasi dalam bahasaGorontalo. Kata modu'a'berdoa'berasal dari morfem mo ${ }^{\bullet}$ sebagai imbuhanyang dilekatkan di depan kata dasar, dan berasal dari kata dasar $\boldsymbol{d u} \boldsymbol{u}^{\boldsymbol{a}}$ 'doa'. Kata du'a bermakna doa dan merujuk pada kelas kata nomina sedangkan kata modu'a bermakna berdoa dan berkelas kata verba karena makna kata modu'a menerangkan sebuah tindakan atau kata keyja yaitu berdoa. Kata du'a 'doa'yang menjadi modu'a 'berdoa'dikategorikan sebagai kata yang mengalami derivasi dalam bahasa Gorontalo dengan dasar bahwa makna kata dan kelas kata pada bentuk dasarnya berbeda dengan makna kata yang mendapat afiks prefiks $\boldsymbol{m o}$-di awal kata dasarnya.

b. Prefiks mohi- digabungkan dengan Nomina menjadi Verba Kalimat (1)

Ja lipata mohisolopu wonu mona'omo tabiyato tihi.

Artinya:

Jangan lupa memakai sandal kalau pergi salat ke masjid.

Kalimat 1 di atas mengandung kata berderivasi, yaitu kata mohisolopu yang berarti memakai sepatu. Kata mohisolopu 'memakai sepatu'berkelas kataverba, sedangkan kata 
dasarnya solopu 'sandal' berkelas kata nomina. Sehingga, kata mohisolopu dikategorikan sebagai kata yang berderivasi dalam bahasa Gorontalo.

c. Prefiks ngo- digabungkan dengan Nomina menjadi Numeralia

\section{Kalimat 1}

Ngoliteri madidu'u

Artinya:

Satu liter telah habis

Data (kalimat1) di atas memperlihatkan bahwa kata ngoliteri merupakan kata yang mengalami derivasi dalam bahasa Gorontalo. Kata ngoliteri terdiri atas kata dasar literi dengan imbuhan ngo-yang disematkan diawal kata literi yang menjadi ngoliteri. Penambahan imbuhan ngo-pada kata literi membawa makna dan kelas kata yang berbeda, yaitu kata literi berarti liter dan berkelas kata nomina sebagai kata yang menerangkan sebuah benda,berubah menjadi ngoliteri yang berarti satu liter dan berkelas kata numeralia akibat makna satu liter merujuk pada angka atau jumlah dalam liter. Sehingga, kata ngoliteri yang berasal kata dasar literi dengan penambahan imbuhanprefiks ngo-di awal kata literi menjadi ngoliteri termasuk dalam kata yang mengalami derivasi dalam bahasa Gorontalo, dengan dasar makna yang dihasilkan akibat kata yang mendapat prefiks ngo- telah berubah makna dan kelas kata dari makna dan kelas kata pada kata dasarnya.

\section{d. Sufiks-lo digabungkan dengan Nomina menjadi Verba}

\section{Kalimat (1)}

Mayilo hengu binte botiye maamo wali masinalo.

Artinya:

Sudah kering milu ini, sudah bisa digiling.

Kalimat 1di atas, mengandung satu kata yang berderivasi, yaitu kata masinalo 'digiling'. Kata masinalo 'digiling'berasal dari kata masina 'mesin' yang berkelas kata nomina, sedangkan kata masinalo 'digiling' berkelas kata verba. Sehingga, kata masinalo 'digiling'dinyatakan sebagai kata berderivasi, karena makna dan kelas kata yang dihasilkan berbeda dari bentuk dasarnya.

\section{Pembahasan}

\section{Infleksi}

Menurut Suifullah (dalam Pohan, 2019: hlm. 110), infleksi merupakan proses pembentukan kata baru dengan menambahkan imbuhan terhadap suatu kata yang tidak 
mengubah kelas kata. Dengan kata lain, jika suatu kata mendapat prefiks (awalan), sufiks (akhiran), ataupun infiks (sisipan), kelas kata dari kata tersebut masih sama.

Menurut Verhaar (dalam Pohan, 2019: hlm. 114) bahwa terdapat dua golongan bawahan yang terpenting dalam paradigma morfemis adalah golongan yang berdasarkan infleksi dan golongan yang berdasarkan derivasi. Golongan fleksi atau infleksional adalah daftar paradigma yang terdiri atas bentuk-bentuk dari kata yang sama, sedangkan derivasi adalah daftar yang terdiri bentuk-bentuk kata yang tidak sama, misalnya bentuk mengajar dan diajar merupakan dua bentuk dari kata yang sama, yaitu mengajar, sedangkan bentuk mengajar dan pengajar merupakan dua kata yang berbeda (verba dan nomina), dengan kata lain, infleksi atau morfologi infleksional adalah proses morfemis yang diterapkan pada kata sebagai unsure leksikal yang sama, sedangkan derivasi atau morfologi derivasional adalah proses morfemis yang mengubah kata sebagai unsur leksikal tertentu menjadi unsur leksikal yang lain. Semua perubahan afiksasi yang melampaui identitas kata disebut derivasi, sedangkan yang mempertahankan identitas kata disebut infleksi. Infleksi adalah bentukbentuk kata yang berbeda dari paradigma yang sama, sedangkan derivasi adalah bentuk kata yang berbeda dari paradigma yang berbeda. Berikut adalah uraian tentang afiks-afiks yang ditemukan mengalami proses infleksi dalam bahasa Gorontalo.

Dalam (Putrayasa, 2008: hlm. 113) membagi infleksi dalam dua kategori, yaitu afiks formator infleksional, dan afiks majemuk infleksional. Berikut adalah uraiannya.

\section{Afiks Formator Infleksional}

Afiks formator infleksional adalah afiks-afiks yang membentuk kata dasar sifatnya tidak mengubah kelas kata (Putrayasa, 2008: hlm. 113).

a. Prefiks mo- digabungkan dengan Verba

Prefiks mo- merupakan imbuhan bahasa Gorontalo yang terdapat di awal kata. Biasanya imbuhan mo- ini dilekatkan dengan kata kerja, karena imbuhan mo- memiliki makna sedang melakukan pekerjaan (Pateda, 2001: hlm. xv). Oleh karena itu, imbuhan mo- yang digabungkan dengan kata kerja adalah katayang mengalami infleksi dengan alasan kata yang mendapat imbuhan atau mo- tersebut tidak mengubah makna dan kelas kata sesuai kata dasamya. Data yang ditemukan mengalami infleksi dengan imbuhan mo- di depan kata dasarnya adalah kata mopetu'a 'terkilir', molilimelo 'berdebar', mohuheto 'mencuci', 
mololohu'mencari', modepito 'mengantar', 'molonggalo', 'membongkar', mohapali'menghafal', mohilingo 'menggiling', dan momolulo 'membakar'.

b. Prefiks popo- digabungkan dengan Verba

Prefiks popo- adalah imbuhan yang disematkan di awal kata dalam bahasa Gorontalo. Kalau imbuhan popo-dilekatkan dengan kata verba, kata yang menjadi kombinasinya harus berakhiran lo atau -po, sedangkan kalau melekat pada nomina atau kata benda, dimaknai sebagai kata yang menerangkan sebuah alat, misalnya kata bate menjadi popobate yang berarti yang dipakai sebagaibatik (Pateda, 2001: hlm. xvi). Data yang ditemukan mendapat imbuhan popo- adalah kata halantuyiyolo'balikkan'. Kata ini tidak mengalami perubahan makna serta tidak mengalami perubahan kelas kata karena kata yang dihasilkan akibat imbuhan popo-tersebut tetap bermakna sama, yaitu popohalantuyiyolo bermakna dibalikkan dan berkelas kata sama, yaitu verba. Sehingga, kata popohalantuyiyolo' dibalikkan' dinyatakan sebagai kata yang mengalami infleksi dalam bahasa Gorontalo.

c. Prefiks lo- digabungkan dengan Verba

Prefiks lo- merupakan imbuhan yang terdapat diawal kata dalam bahasa Gorontalo. Prefiks lo- dimaknai sebagai kata yang menyatakan pekerjaan itu telah diselesaikan atau dianggap telah dilakukan (Pateda, 2001: hlm. xvi). Data yang ditemukan mengalami infleksi dengan menyematkan afiks $l o$ - di awal kata dasarnya adalah kata lota'odu 'mendaki',dan kata lohama 'mengambil'. Kedua kata tersebut dari kata dasar ta'odu 'dakilnaik', dan hama'ambil', yang menyatakan sebuah kegiatan telah dilakukan. Walaupun kedua kata tersebut telah bermakna kejadian telah berlalu, namun kedua kata tersebut tetap digolongkan dalam infleksi, karena kata lota'odu 'mendaki' dan kata lohama 'mengambil' adalah kata yang menghasilkan makna tidak jauh berbeda dengan kata dasarnya, yaitu ta'odu 'dakilnaik', dan hama 'ambil'. Kelas kata yang dihasilkan oleh kedua kata tersebut sama-sama berkategori verba karena menunjukkan sebuah kata keyja.

d. Prefiks moti- digabungkan dengan Verba

Prefiks moti- merupakan imbuhan yang disematkan di depan kata dasarnya. Imbuhan moti- adalah imbuhan yang menyatakan waktu yang akan datang (Pateda,2001:xvi). Data yang ditemukan adalah moti'oyohu 'berenang'. Kata 
moti'oyohu 'berenang' berkata dasar oyohu 'renang' dan kedua kata tersebut berkelas kata verba.

e. Infiks -il- Digabungkan dengan Verba

Infiks-il-merupakan imbuhan yang digunakan dalam bahasa Gorontalo. Keberadaan infiks - il- yaitu berada di tengah-tengah kata. Misalnya pada kata delo menjadi dilelo akibat infiks -il-yang di sematkan di depan kata dasarnya. Dalam penelitian ini, infleksi yang menggunakan infiks -il- di tengah katanya terjadi pada kata hilama. Sebab, imbuhan-il-yang disematkan di tengah kata, tidak membawa perubahan kelas kata dan tidak membawa perubahan makna kata sesuai makna dan kelas kata pada bentuk dasarnya. Sehingga, infiks - $\boldsymbol{i}$ l. dinyatakan sebagai afiks yang menunjang proses pembentukan infleksi dalam bahasa Gorontalo.

f. Sufiks-lodigabungkan dengan Verba

Sufiks-lo merupakan imbuhan yang terdapat di akhir kata. Dalam bahasa Gorontalo,sufiks-lo diartikan sebagai imbuhanyang menyatakan di, di...kan, mempunyai, mengandung, menyatakan sifat, dan menyatakan perintah ataugjakan. Dat ayang ditemukan mengandung sufiks -lo adalah kata daha, hama, ponga yang menjadi dahalo 'dïaga', longgalolo 'dibongkar',dan luwodulo'ditebang'. Ketiga data ini, memiliki makna yang sama sesuai kata dasarnya masing-masing dengan kelas kata yang sama juga. Hal tersebut diakibatkan adanya imbuhan-lo yang dilekatkan di akhir kata tidak mengubah makna dan kelas kata sesuai maknadankelaskatapadakata dasar. Ini membuktikan bahwa kata dahalo 'dïaga', longgalolo 'dibongkar', dan luwodulo 'ditebang' mengalami infleksi dalam bahasa Gorontalo.

\section{AfiksMajemuk Infleksional}

Afiks majemuk infleksional merupakan afiks konfiks yang membentuk kata,dan sifatnya mengubah kelas kata. Berikut adalah afiks majemuk yang ditemukan mengalami infleksi dalam bahasa Gorontalo.

\section{Konfiks po'o- dan -lo Digabungkan dengan Verba}

Konfiks po'o- dan-lo merupakan imbuhan yang dikombinasikan dalam bahasa Gorontalo dan disematkan di awal dan di akhir kata. Konfiks poo-dan-lo termasuk salah satu afiks yang menunjang proses pembentukan infleksi dalam bahasa Gorontalo. 


\section{Derivasi}

Suparman dan Clark (dalam Putrayasa, 2017: hlm. 103) menjelaskan bahwa derivasi atau derivasional adalah proses morfologis karena afiksasi yang menyebabkan terbentuknya berbagai macam bentukan dengan ketentuan bahwa bentukan tersebut berubah kelas katanya. Derivasi juga menghasilkan leksem baru yang diderivasi, misalnya kata 'jalan' mendapat imbuhan derivasi 'ber' menjadi 'berjalan', proses ini menciptakan leksem dengan makna baru dengan kelas kata yang berbeda (Pohan, 2019: hlm. 111). Selain itu, Nida (dalam Pohan, 2019: hlm. 111) mengemukakan bahwa derivasi digunakan untuk menetapkan kata-kata dalam suatu kelas dan umumnya mengubah kelas kata.

Menurut Suifullah (dalam Pohan, 2019: hlm. 110), derivasi adalah proses pembentukan kata dengan menambahkan imbuhan terhadap kata dasar, dengan ketentuan afiks yang disematkan dapat mengubah kelas kata ataupun makna kata dasar tersebut. Samsuri (dalam Putrayasa, 2017: hlm. 103) menjelaskan bahwa derivasi merupakan konstruksi yang berbeda distribusinya dari dasamya.

Identitas bentuk yang dihasilkan dalam proses pembentukan derivatif tidak sama dengan identitas leksikal bentuk dasamya (Chaer, 2015: hlm. 37). Menurut (Pohan, 2019: hlm. 109) bahwa derivasi merupakan proses pengubahan bentuk kata yang mengubah identitas. Arnoff dan Fudeman (dalam Pohan, 2019: hlm. 109) menjelaskan bahwa derivasi meliputi penciptaan suatu leksem dari leksem lainnya. Sejalan dengan pendapat di atas, Boiij (dalam Pohan, 2019: hlm. 109) mengemukakan bahwa derivasi dibedakan dari segi fungsinya. Derivasi leksem Aronoff dalam Christina (2018) mengemukakan bahwa secara morfologis derivasi dapat dilakukandengan mengawinkan pola formasi kata dengan formasi leksem.

Dalam bahasa Gorontalo, pembentukan derivasi dikenal dengan istilah transposisi. Menurut Harimurti (dalam Pateda, 2002: hlm. 162) bahwa transposisi adalah proses atau hasil perubahan fungsi atau kelas kata tanpa penambahan apa-apa. Berikut adalah afiks-afiks yang mengalami proses derivasi dalam bahasa Gorontalo sesuai data yang ditemukan.Putrayasa, 2008: hlm. 105) menjelaskan bahwa derivasi dibagi dalam dua kategori, yaitu kategori pertama adalah Afiks Formator Derivasional, dan kedua adalah Afiks Majemuk Derivasional. Berikut adalah uraiannya. 


\section{Afiks Formator Derivasional}

Afiks formator derivasional merupakan afiks yang membentuk kata dan sifatnya mengubah kelas kata (Putrayasa, 2008: hlm. 103). Di bawah ini adalah uraian afiks formator derivasional.

\section{a. Prefiks mo- Digabungkan dengan Nomina menjadi Verba}

Prefiks mo- merupakan imbuhan yang sematkan di awal kata dasar. Dalam penelitian ini,prefiks mo- yang digabungkan dengan nomina adalah afiks yang menunjang terjadinya pembentukan derivasi dalam bahasa Gorrontalo. Data yang ditemukan mengalami perubahan makna dan kelas kata setelah disematkan afiks $\boldsymbol{m o}$-adalah kata du'a 'doa',dan lombuli 'pedagang kecil', heyidu 'sisir', dan silita 'cerita' yang berubah menjadi modu'a 'berdoa', molombuli' menjual kembali', moheyidu 'menyisir, dan mosilita 'bercerita'. Perubahan tersebut terlihat dari makna pada kata dasar,dan makna pada kata yang mendapat afiks. Kategori kelas kata pun berubah, yang awalnya pada kata dasar nomina, kini menjadi verba setelah kata dasamya mendapat afiks modi depan kata dasar tersebut. Sehingga, ketiga kata tersebut dinyatakan sebagai kata yang mengalami derivasi dalam bahasa Gorontalo.

\section{b. Prefiks mohi- Digabungkan dengan Nomina Menjadi Verba}

Prefiks mohi- merupakan imbuhan yang terletak di awal kata. Data yang berhasil ditemukan mengalami infleksi adalah kata mohisolopu 'memakai sandal', mohihu'alimo 'memakai cincin', dan mohi jaketi 'memakai jaket' yang berkelas kata verba. Ketiga kata tersebut, telah berubah makna dan kelas kata dari kata dasarnya, yaitu solopu 'sendal', hu'alimo'cincin',dan jaketi'jaket', yang ketiga kata dasar itu berkelas kata nomina. Sehingga, kata mohisolopu 'memakai sandal', mohihu'alimo 'memakai cincin', dan mohijaketi'memakai jaket'termasuk dalam kata yang mengalami infleksi dalam bahasa Gorontalo.

\section{c. Prefiks ngo-Digabungkan dengan Nomina Menjadi Numeralia}

Prefiks ngo- adalah imbuhan dalam bahasa Gorontalo yang disematkan di awal kata. Imbuhan ngo- dalam penelitian ini menjadi penunjang pembentukan derivasi, yang ditemukan pada kata literi 'liter', topi 'sisir', kado 'karung'. Ketiga data yang ditemukan tersebut mengalami penambahan afiks ngo-diawal kata, yang berubah maknanya menjadi ngoliteri 'satu liter',ngotopi 'satu sisir', ngokado'satukarung'. Perubahan makna kata pada kata dasardi atas, membawa perubahan kelaskata 
juga,yang awalnya berkelas kata nomina berubah menjadi verba. Perubahan makna dan kelas kata tersebut terjadi setelah disematkan afiks di depan kata dasarnya. Sehingga, ketiga kata tersebut dinyatakan sebagai kata yang mengalami derivasi dalam bahasa Gorontalo.

\section{d. Sufiks-lo Digabungkan dengan Nomina menjadi Verba}

Sufiks-lo merupakan imbuhan bahasa Gorontalo yang terletak di akhir kata. Menurut (Pateda, 2001: hlm. xix) bahwa sufiks - lo dapat diartikan sebagai imbuhan yang menyatakan di-contohnya kata luluto 'hapus' menjadi lulutolo 'dihapus', juga imbuhan-lo dapat menyatakan kata mempunyai l mengandung, contohnya kata kukudu 'kudis' menjadi kukudulo 'mengandung kudis berkudis kudisan', juga imbuhan -lo dapat menyatakan kata yang mempunyai sifat misalnya kata lantingo menjadi lantingalo 'malas', serta imbuhan -lo dapat menyatakan perintah dan ajakan, misalnya kata dulo'mari' menjadi dulolo 'marilah'.

Data yang ditemukan mengalami perubahan kelas kata dan perubahan makna kata adalah kata masina 'mesin' dan pomba 'pompa' yang berkelas kata nomina berubah menjadi berkelas kata verba karena kedua kata dasar tersebut mendapat imbuhan -lo diakhir kata dasarnya menjadi masinalo 'digiling', dan pombalo 'dipompa'. Perubahan kelas kata dan perubahan makna kata tersebut membawa kata masinalo 'digiling' dan pombalo 'dipompa' termasuk dalam kata berderivasi dalam bahasa Gorontalo.

\section{Afiks Majemuk Derivasi}

Afiks majemuk derivasional adalah afiks kombinasi yang sifatnya mengubah kelas kata (Putrayasa, 2008: hlm. 105). Berikut adalah uraiannya.

\section{Konfik spo- dan - lo Digabungkan dengan Nomina}

Konfiks po- dan -lo merupakan imbuhan yang digabungkan antara awalan mo- dan akhiran -lo. Data yang ditemukan mengalami infleksi dalam bahasa Gorontalo yang menggunakan imbuhan konfiks po- dan -lo adalah kata poyitohulo 'bermainlah'.

\section{Simpulan}

Berdasarkan hasil dan pembahasan dapat disimpulkan bahwa afiks infleksi dan afiks derivasi dalam bahasa Gorontalo ditemukan pada imbuhan prefiks, iniks, sujiks dan konjiks, dengan ciri bahwa imbuhan yang disematkan di kata dasarnya, haruslah mengubah makna dan kelas kata (derivasi), juga harus mempertahankan makna dan kelas kata sesuai kata dasarnya (infleksi). Semua perubahan afiksasi yang melampaui identitas kata disebut 
derivasi, sedangkan yang mempertahankan identitas kata disebut infleksi Infleksi adalah bentuk - bentuk kata yang berbeda dari paradigma yang sama, sedangkan derivasi adalah bentuk kata yang berbeda dari paradigma yang berbeda.

\section{DaftarPustaka}

Anggriani, V. (2020). "Prefiks Bahasa Kaili Dialek Ado Desa Pakuli Utara Kecamatan Gumbasa Kabupaten Sigi”. Jurnal Universitas Tadulako. Vol. 5. No.4.

Anggraini, A. E. dan Bayu, J. T. (2019). Morfologi "Proses Pembentukan Kata". Jakarta: Pustaka Mandiri.

Mahsun. (2012). Metode Penelitian Bahasa (Edisi Revisi). Jakarta: RajaGrafindo.

Moleong, J. L. (2006). Metodologi Peneltian Kualitatif (Edisi Revisi). Bandung: Remaja Rosdakarya.

Nur.Tajudin. (2018). Infleksi dan Derivasi dalam Bahasa Arab Analisis Morfologi.Vol. 16. No. 2.

Pohan, J. E. (2019). Morfologi Bahasa Indonesia. Yogyakarta: Budi Utama.

Parera, J. D. (2007). Morfologi. Jakarta: Gramedia.

Pohan, J. Efendi. (2019). Morfologi Bahasa Indonesia. Yogyakarta: Budi Utama.

Putrayasa, I. B. (2008). Kajian Morfologi (Bentuk Derivasional dan Injleksional). Bandung: Refika Aditama.

Pateda, M. (2001). Kamus Bahasa Gorontalo-Indonesia. Jakarta: Balai Pustaka.

Pateda, M. (2002). Morfologi. Gorontalo: Viladan Gorontalo.

Pateda, M. (1999). Kaidah Bahasa Gorontalo. Gorontalo: Viladan Gorontalo dan STKIP Gorontalo.

Romli, M. (2015). Afiksasi dalam Bahasa Indonesia dan Bahasa Sunda. Jumal Sasindo Unpam. Vol. 2. No. 2.

Weking, T. C. (2018). Derivasi Bahasa Lamaholot Dialek Baipito. Jumal Metalingua Universitas Nusa Cendana. Vol. 16. No. 2. 